\title{
Control of the mud pulse method the loosening of coal layers by amplitude-frequency recommendation of acoustic signal by the APSS-1 system
}

\author{
Vasyl Zberovskyi ${ }^{1, *}$ \\ ${ }^{1}$ Institute of Geotechnical Mechanics named by N. Poljakov of National Academy of Sciences of \\ Ukraine, 49005, Dnipro, Simferopolska Str., 2a, Ukraine.
}

\begin{abstract}
The article presents the research results of parameters of the mud pulse method the loosening of outburst-hazardous coal seams in the faces of development workings system APSS-1. The results of the monitoring and evaluation of the effectiveness of pulse loosening a coal seam in static and pulsed mode of injection fluid, the main provisions of the developed techniques and additions to methods of acoustic control with a view to their use in hydroimpulsive impact. It is established that application of pulsed injection of fluid leads to a decrease in the active phase of the process pulse loosening a coal seam, to increase its efficiency and increase the speed of the output.
\end{abstract}

\section{Introduction}

The safety of mining operations in seams of endangered and dangerous on sudden emissions of coal and gas is regulated by "Rules ..." [1]. Forecast of gas-dynamic events (GDE) and evaluation of the effectiveness of prevention techniques held at the opening of the strata at the preparatory workings and mining. Therefore, the development of a new method of pulse cultivation of coal seams in the faces of development workings was carried out with the use of prediction and control of life threatening situations: initial speed of gas emission, the amplitude-frequency characteristics of the acoustic signal system APSS-1, acoustic emission massif apparatus ZUA-98 [2-9].

The monitoring and evaluation of the effectiveness of pulse cultivation by the results of the control system APSS-1 was performed in the SP Shakhtoupravlinnia «SukhodilskeSkhidne»PAT «Krasnodonvuhillia» in terms of the reservoir $\mathrm{i}_{3}{ }^{1}$ horizon of 915 meters. A complex of measures to prevent life threatening situations, it was envisaged that the forecast "is dangerous" performed activities to pulse loosening a coal seam with the subsequent control of the effectiveness of using the apparatus of APSS-1 [10-13]. If the control and evaluation of the effectiveness of pulse loosening a coal seam in the mode of pulse discharge of the liquid by an initial speed of gas emission has not caused difficulties, the use of the system APSS-1 and equipment ZUA-98 required additional research and adjustment of parameters of acoustic control. This defined the purpose and objectives of the

*Corresponding author: avalansh@ua.fm 
research.

In this work the results of research of hydraulic impulse loosening a coal seam $\mathrm{i}_{3}{ }^{1}$ horizon of 915 meters in the conditions of Shakhtoupravlinnia "Sukhodilske-Skhidne" PAT "Krasnodonvuhillia" in the amplitude-frequency characteristics of the acoustic signal system APSS-1.

\section{The main content of the work}

For the discharge of fluid used serial pump installation 2UGNM, UNI-01 and the UNR. The hydro-pulse impact device [2] used a cavitation generator CG-2.5. The depth of drilling production wells $l_{\mathrm{w}}$ ranged from 6.0 to 8.0 meters, filtration of the well $l_{\mathrm{f}}=2.0 \mathrm{~m}$, the depth of the sealing water seal "Taurus" $l_{\mathrm{s}} \geq 4.0 \mathrm{~m}$.

During the work on the hydrofluidization of the coal seam, the parameters of its gasdynamic state, the parameters of the static and pulsed modes of fluid injection were investigated. Evaluation of the effectiveness of the method made by comparing the characteristics of the acoustic signal. Technological wells, test holes, and seismograph were located in the face of development in accordance with the technological scheme of pulse loosening a coal seam and methods for control of acoustic parameters [1].

Evaluation of the effectiveness of activities carried out by matching the parameters of the normative way of pulse loosening a coal seam in the static mode of injection fluid and the method of pulse cultivation. During the work carried out 35 cycles of static discharge fluid and 30 cycles of hydroimpulsive impact. The total length of the workings was about $1.2 \mathrm{~km}$ away.

Pulse loosening a coal seam under static liquid injection stop at the command of the system operator APSS-1 "the active process completed" if the fall discharge pressure of not less than $30 \%$ of the set. The results of the control pulse loosening a coal seam recorded in the log event and stored in the computer database of the operator of the APSS-1.

As an example, table 1 shows the thinned data results of research on the state of the array when of pulse loosening a coal $\mathrm{i}_{3}{ }^{1}$ in the bottom 25 of the ventilation drift.

Table 1. The results of studies of pulse loosening a coal $\mathrm{i}_{3}{ }^{1}$ seam reservoir in the bottom 25 of the ventilation roadway system APSS-1 with the software package "Prognoz 4.0".

\begin{tabular}{|c|c|c|c|c|c|c|c|}
\hline \multirow{2}{*}{$\begin{array}{c}\text { Mode } \\
\text { discharge, } \\
\text { mark }\end{array}$} & \multirow{2}{*}{$\begin{array}{l}\# \text { of } \\
\text { well }\end{array}$} & \multirow{2}{*}{$\begin{array}{c}K_{V} \\
\text { outburst } \\
\text { hazard }\end{array}$} & \multirow{2}{*}{$\begin{array}{c}\text { Discharge } \\
\text { zone, } \\
\text { m }\end{array}$} & \multirow{2}{*}{$\begin{array}{c}F_{p} \\
\text { (resonance } \\
\text { frequency) }\end{array}$} & \multirow{2}{*}{$\begin{array}{c}F_{p} \\
\text { secondary }\end{array}$} & \multicolumn{2}{|c|}{$\begin{array}{l}\text { The exposure } \\
\text { time, (minutes) }\end{array}$} \\
\hline & & & & & & $\begin{array}{l}\text { active } \\
\text { process }\end{array}$ & just \\
\hline pulse & 1 & 0.69 & 4.3 & $60 ; 120 ; 160$ & 113.3 & 16 & \multirow{2}{*}{16} \\
\hline РК21+7.5 & 2 & 0.67 & 6.0 & $60 ; 120 ; 160$ & 113.3 & 0.0 & \\
\hline pulse & 1 & 0.49 & 6.0 & $80 ; 120 ; 140$ & 113.3 & 3 & \multirow{2}{*}{23} \\
\hline РК22+9.5 & 2 & 1.89 & 6.0 & $60 ; 360 ; 480$ & 300 & 20 & \\
\hline pulse & 1 & 0.79 & 6.0 & $60 ; 140 ; 200$ & 133.3 & 19 & \multirow{2}{*}{21.5} \\
\hline РК23+4.0 & 2 & 2.06 & 3.0 & $20 ; 160 ; 180$ & 120 & 2.5 & \\
\hline static & 1 & 7.65 & 0.0 & $\begin{array}{c}240 ; 280 \\
560\end{array}$ & 360 & 14,3 & \multirow[b]{2}{*}{56.3} \\
\hline $\mathrm{PK} 24+5.0$ & 2 & 6.49 & 2.8 & $\begin{array}{c}240 ; 280 \\
320\end{array}$ & 280 & 42 & \\
\hline static & 1 & 1.31 & 1.3 & $\begin{array}{c}140 ; 260 ; \\
280\end{array}$ & 226.6 & 20 & \multirow{2}{*}{36} \\
\hline PК25+0.5 & 2 & 3.93 & 0.0 & $\begin{array}{c}180 ; 280 \\
360\end{array}$ & 273.3 & 16 & \\
\hline
\end{tabular}


The use of software complex "Prognoz 4.0" allowed to maintain control of the zone of discharge, record the discharge pressure of the liquid, the period of active process pulse loosening a coal seam and the ratio of outburst hazard. On the computer monitor of the operator in real-time display low-frequency component and the resonance frequency of the acoustic signal, evaluation of the effectiveness of pulse loosening a coal seam and safe recess depth. To control the pulse cultivation was adjust the low-frequency component and the resonance frequency. An example of the results of research and mapping the frequency components shown in Figure 1 and 2 [8].

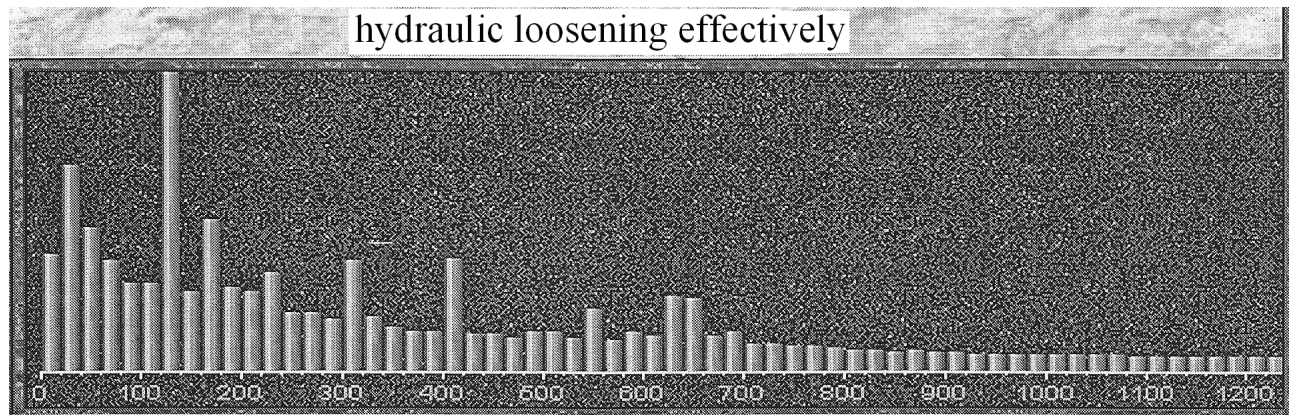

Fig. 1. The distribution of resonance frequencies in static mode, the liquid injection.

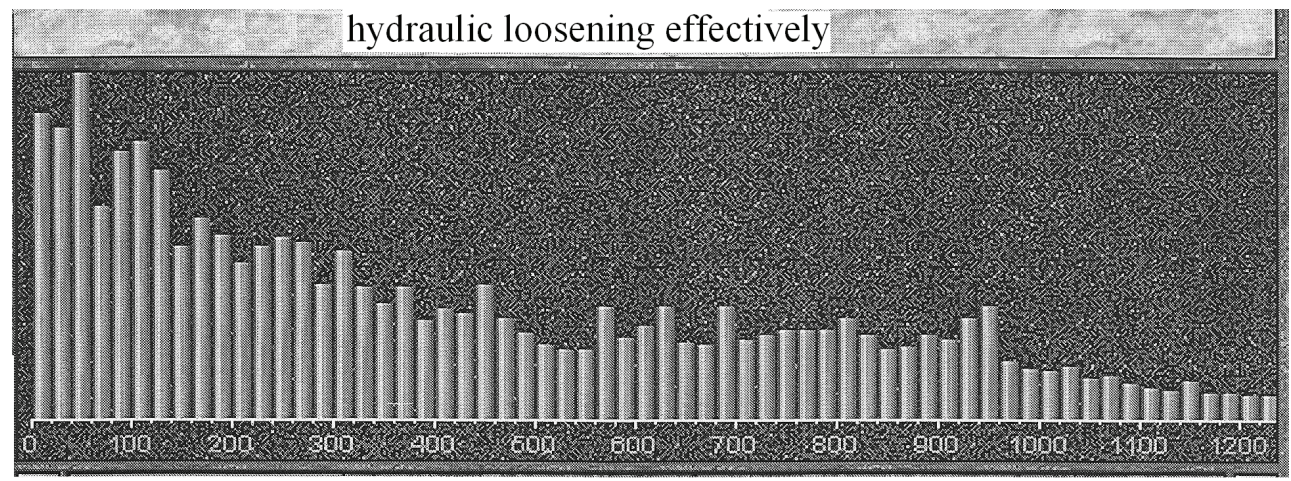

Fig. 2. The distribution of resonance frequencies with pulse effects.

The maximum and final pressure of the pressurization fluid in the borehole was determined by the manometer of the device [2]. From the bottom output information is transmitted to the operator of the APSS-1 and recorded in the computer database. Comparison of the results of control of static and pulsed modes of the discharge has allowed to establish that pulse cultivation leads to a reduction in the cost of preventive measures. The flow rate and time of discharge is reduced by more than $50 \%$, and the active stage of the process of pulse loosening a coal seam. The discharge zone increases from 3.5 to 6 meters.

Simultaneously with monitoring the effectiveness of pulse loosening a coal seam system APSS-1 was conducted acoustic studies of stress-strain state of rocks in the roof of the reservoir. It is established that the influence of the process of pulse exposure is fixed up to $22.5 \mathrm{~m}$ (Fig. 3). It shows the development of deformation in the rocks of the seam roof at a distance of over 10 meters and uniform (without delay) their development [8].

The definition of weak contacts, which are formed in the array enclosing rocks when pulse loosening a coal seam, allowed in real time to process the acoustic signal and determine the ratio of outburst hazard, the unloading area and the effectiveness of By results of researches it was found that the pulse loosening in the process of deformation 
involved a much larger portion of rock masses. This reduces ahead of the bottom output is not less than $25 \%$ of the tension of the array $K_{V}$ and increased to $74 \%$ of the value of the low-frequency component. Collectively, the use of hydro pulse action leads to increased efficiency pulse loosening a coal seam, increase safe digging coal from 4 feet to the depth of drilling and allows you to increase the speed of production in 2-3 times.

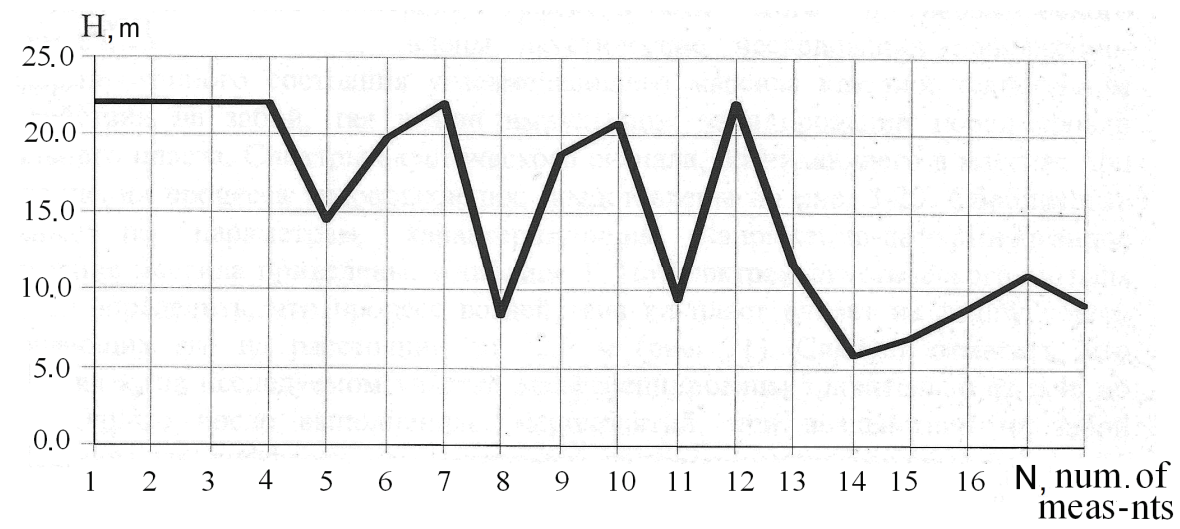

Fig. 3. The distribution of weak contacts in the roof rocks.

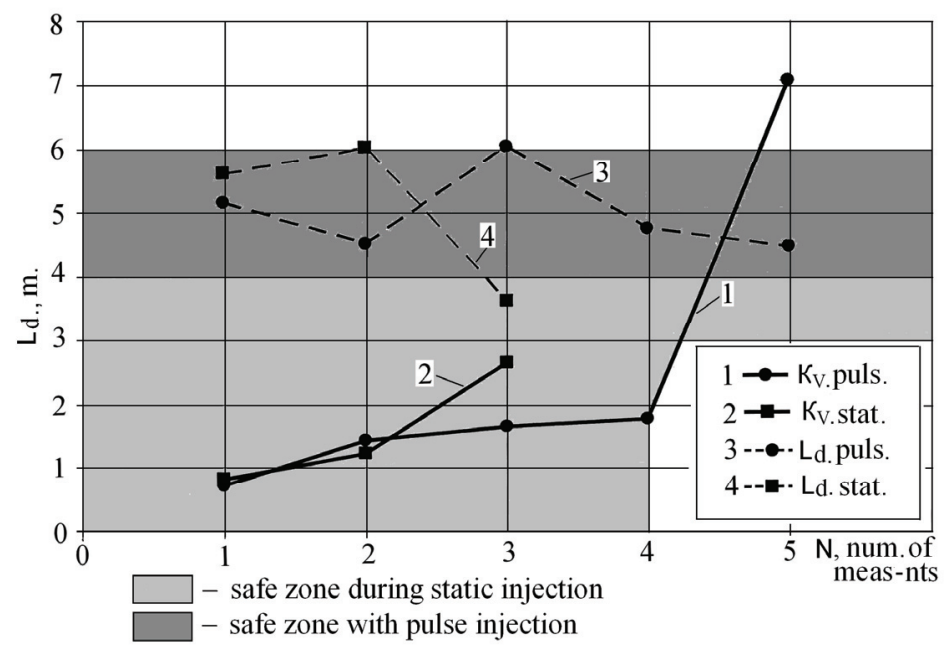

Fig. 4. An example of mapping the results of the determination zone discharge system APSS-1 under static and pulsed modes of the discharge: $K_{V}$ - outburst hazard; $L_{d}-$ discharge zone.

However, it should be noted that in the process of conducting a mining pilot studies, there were cases when due to technological reasons pulse loosening a coal seam was carried out unevenly (7 to $15 \mathrm{~m})$. In these areas, after 2-3 cycles $(1.2-1.8 \mathrm{~m})$ of continuous operation of the harvester, the coefficient of outburst hazard was increased. In these conditions, visual inspection of slaughter output in the process of discharge of the liquid, the surface layer is covered with scales of supermelodic separated from the coal in an atmosphere of development and can be seen in the beam of light. The feelings attached to the layer of the palms and their Association with the manifestation of the vibration on the stand, the frequency range is from 900 to $1500 \mathrm{~Hz}$.

The results of these observations indicate that to maintain the maximum rate of excavations necessary to carry out events every 6-7 meters, which corresponds to the depth of drilling production wells. 


\section{Conclusions}

Comparison of average parameter data static and pulsed modes of the discharge fluid, mounted on the control parameters the efficiency of get rows data system APSS-1 allowed us to draw the following conclusions.

1. Adjust the low-frequency component and the resonance frequency of the acoustic signal allowed to consider the frequency component of dynamic load pulse discharge. It is possible to use the instrument of APSS-1 for control and assessment of efficiency of pulse loosening a coal seam, dangerous on sudden emissions of coal and gas.

2. Found that if you pulse the loosening of coal layers in the process of deformation involves strata of rocks, with a capacity of up to $22.5 \mathrm{~m}$. This leads to a reduction of at least $25 \%$ of the tension of the array $K_{V}$, uniform (without delay) the development of deformations in the roof of a coal seam at a distance of over $10 \mathrm{~m}$.

3. The use of hydro pulse coal seams allows in times to reduce the active stage of the process of hydrocyclone and increase the safe zone of excavation to the depth of drilling. To maintain the maximum rate of the workings of events should be held regularly at intervals of 6-7 meters.

The author express gratitude to the scientific employees of Makeyevka research Institute for their assistance in conducting studies of hydro-pulse impact in conditions of mines of PAT "Krasnodonvuhillia".

\section{References}

1. Mining rule in seams prone to gas-dynamic phenomena. (2005) [Standard Coal Ministry of Ukraine SIU 10.1.001740088], Coal Ministry of Ukraine

2. Vasyliev, L.M., Zhulai, Yu.O., Zberovskiy, V.V., Moiseienko, P.Iu., Trokhymets, M.I. (2009) Prystrii dlia hidroimpulsnoho vplyvu na vuhilnyi plast. Patent No 87038 Ukraine

3. Zberovskiy, V.V. (2008). Povysheniye urovnya okhrany truda i bezopasnosti gornykh rabot gidroimpulsnym vozdeystviyem na ugolnyye plasty. Geotekhnicheskaya mekhanika, (74), 112-117

4. Zberovskiy, V.V., Kostandov, Yu.A. (2011). Predelnoe sostoyanie vybrosoopasnykh uholnykh plastom pri ikh hidrorykhlenii s uchetom soprotivlyaemosti uhlya sdvihu. Zbirnyk naukovykh prats NGU, 36 (2), 36-43

5. Zhulay Y., Zberovskiy V., Angelovskiy A., Chugunkov I. (2012.) Hydrodynamic cavitation in energy-saving technological processes of mining sector. Geomechanical processes during underground miming. - Leiden, The Netherlands: CRC Press/Balkema, 51-56

6. Zberovskiy, V.V., Zhulai, Yu.O., Vasylyev, D.L., Nikiforov, A.V. Kolchyn, H.I., Anhelovskyi, O.A., Chuhunkov, I.F., Niskevych, O.M. (2012) Sposib hidroimpulsnoho rozpushuvannia vuhilnykh plastiv. Patent No 73023 Ukraine

7. Vasilyev, L.M., Zberovskiy, V.V. (2013). Gidroimpulsnoe ryhlenie ugolnyh plastov pri provedenii podgotovitelnyh vyrabotok, Coal of Ukraine, 2, 44-47

8. Zberovskiy, V.V. (2017) Otsenka effektivnosti gidroimpulsnogo vozdeystviya na ugolnyy plast metodami akusticheskogo kontrolya. Geotekhnicheskaya mekhanika, (132), 74-84

9. Zberovskyi, V., Bubnova, O., Babii, K. (2018) Specifics of hydro-loosening of coal seams with account of rocks displacement parameters // E3S WebConferences, Ukrainian School of Mining Engineering, 60 (00025), https://doi.org/10.1051/e3sconf/20186000025

10. Zhulay, Yu.A., Vasilyev, L.M., Zberovskiy, V.V., Moisennko, P.Yu., Trokhimets 
N.Ya. (2007) Intensifikatsiya gazovydeleniya iz ugolnogo massiva nagnetaniyem $v$ nego zhidkosti $s$ primeneniyem generatora kavitatsii. Gornyy informatsionnoanaliticheskiy byulleten, (13), 251-259

11. Zberovskiy, V.V. (2007) Rezultaty issledovaniy sredstv impulsnogo nagne-taniya zhidkosti pri gidrorykhlenii ugolnykh plastov v zaboyakh podgotovitelnykh vyrabotok. Geotekhnicheskaya mekhanika, (132), 109-118

12. Angelovskiy, A.A., Chugunkov, I.F., Zberovskiy, V.V., Narivskiy R.N. (2008) Issledovaniye parametrov vysokonapornogo nagnetaniya zhidkosti v vybroso-opasnyye ugolnyye plasty pri provedenii podgotovitelnykh vyrabotok. Geotekhnicheskaya mekhanika, (77), 82-91

13. Zberovskiy, V.V., Pazynych, A.V., Polyakov, Yu.E., Potapenko, A.A., Angelovskiy A.A. (2010). Ocenka ehffektivnosti gidroimpul'snogo vozdejstviya po gazovomu faktoru v zaboyah podgotovitel'nyh vyrabotok. Geotekhnicheskaya mekhanika, (89), 126-133 